\title{
Application of rehabilitation robots - chances and threats within contemporary health care and social care
}

\section{Wykorzystanie robotów rehabilitacyjnych - szanse i zagrożenia w opiece zdrowotnej i społecznej}

\author{
Emilia Mikołajewska ${ }^{1, *}$, Dariusz Mikołajewski ${ }^{2,3}$ \\ ${ }^{1}$ Rehabilitation Clinic, Military Clinical Hospital No. 10 with Polyclinic, Powstańców Warszawy 5, \\ 85-681 Bydgoszcz, Poland \\ ${ }^{2}$ Institute of Mechanics and Applied Computer Science, Faculty of Mathematics, Physics and \\ Technical Sciences, Kazimierz Wielki University, Kopernika 1, 85-074 Bydgoszcz, Poland \\ ${ }^{3}$ Departament of Informatics, Faculty of Physics, Astronomy and Applied Computer Science, \\ 5 Grudziądzka St., 87-100 Toruń, Poland \\ *,**E-mail address: e.mikolajewska@wp.pl , darek.mikolajewski@wp.pl
}

\begin{abstract}
Progress in medical sciences, biomedical engineering and medical robotics provided rehabilitation robots - novel solution regarded as more effective than traditional forms of rehabilitation. Use of rehabilitation robots, despite they are at the beginning of their development, is wide discussed from medical, social, economical and ethical points of view. Paper aims at analysis the extent to which current possibilities in this area are exploited, including chances and threats.
\end{abstract}

Keywords: rehabilitation; physiotherapy; rehabilitation robot; social and ethical implications

\section{STRESZCZENIE}

Postęp nauk medycznych, inżynierii biomedycznej oraz robotyki medycznej przyniósł roboty rehabilitacyjne - nowe rozwiązanie uważane za efektywniejsze od tradycyjnych form usprawniania. Wykorzystanie robotów rehabilitacyjnych, pomimo że są one dopiero na początku swojego rozwoju, jest szeroko dyskutowane z różnych punktów widzenia: medycznego, społecznego, ekonomicznego i etycznego. Celem pracy jest analiza, na ile obecne możliwości w zakresie robotyki rehabilitacyjnej są wykorzystywane, w tym z punktu widzenia szans i zagrożeń.

Stowa kluczowe: Rehabilitacja; fizjoterapia; robot rehabilitacyjny; implikacje społeczne i etyczne 


\section{WPROWADZENIE}

Postęp nauk medycznych powoduje, że rośnie przeżywalność wcześniaków, ciężkich schorzeń (udarów, urazów czaszkowo-mózgowych, uszkodzeń rdzenia kręgowego, chorób metabolicznych i ciężkich zatruć) oraz wypadków (w tym komunikacyjnych). Starzenie się społeczeństw rozwiniętych powoduje, że przybywa osób zagrożonych urazami np. w wyniku upadków) oraz schorzeniami neurodegeneracyjnymi. Jednocześnie pomimo połączonego wysiłku interdyscyplinarnych zespołów terapeutycznych oraz rodzin i opiekunów pacjentów nie zawsze udaje się ich doprowadzić do pełnej poprzedniej sprawności funkcjonalnej. Niesie to za sobą ludzkie dramaty, ale również poważne koszty społeczne (zmiana priorytetów życiowych, konieczność opieki nad pacjentem, spadek jakości życia pacjenta i jego rodziny, poczucie bycia ciężarem i depresja u pacjenta) i ekonomiczne (spadek dochodów, zwiększone wydatki, konieczność wypłaty świadczeń rentowych). Nic zatem dziwnego, że naukowcy i klinicyści poszukują wciąż nowych metod terapeutycznych podwyższających efektywność profilaktyki, leczenia i rehabilitacji. W tym ostatnim obszarze jednym $\mathrm{z}$ najnowszych rozwiązań są roboty rehabilitacyjne [1-4].

Celem niniejszej pracy jest analiza, na ile obecne możliwości w zakresie robotyki rehabilitacyjnej są wykorzystywane, w tym z punktu widzenia szans i zagrożeń.

\section{REHABILITACJA ZROBOTYZOWANA JAKO PROBLEM MEDYCZNY, SPOLECZNY, ETYCZNY I EKONOMICZNY}

Automatyzacja i robotyzacja oferuje szeroki wachlarz innowacyjnych rozwiązań uzupełniających, rozszerzających i/lub zastępujących ofertę placówek opieki zdrowotnej i społecznej dedykowanej osobom niepełnosprawnym, przewlekle chorym (np. osłabionym w okresie powrotu do zdrowia) oraz w podeszłym wieku. Rozsądne wykorzystanie robotów rehabilitacyjnych, wbrew obawom personelu medycznego i opieki społecznej, nie będzie na razie stanowiło zagrożenia dla ich miejsc pracy. Ma za to ogromne znaczenie pozytywne, gdyż obecnie trudno będzie zapewnić wszystkim pacjentom wystarczający poziom terapii i opieki z następujących powodów:

- wykształcenie specjalisty medycznego trwa coraz dłużej ze względu na postępującą specjalizację, a każdy z nas chciałby być leczony/rehabilitowany przez jak najlepszego specjalistę,

- czasochłonność części procedur, w tym rehabilitacji długoterminowej,

- pomimo szybkiego przyrostu pacjentów nie można liczyć na szybki lub wręcz skokowy przyrost specjalistów medycznych,

- szybkość ww. zmian jest dodatkowo limitowana przez ograniczone fundusze na opiekę zdrowotną i społeczną (w tym również w ramach lecznictwa prywatnego), wysokie koszty części świadczeń (w tym ratujących życie czy indywidualnej terapii długoterminowej) oraz ograniczoną infrastrukturę, która również musi sprostać zwiększonemu zapotrzebowaniu na usługi.

Z ww. przyczyn skracanie hospitalizacji dzięki efektywniejszym metodom terapeutycznym oraz przenoszenie części usług poza szpital (do opieki ambulatoryjnej lub domowej) jest po prostu koniecznością. Wpisuje się to w generalny postęp technologiczny w innych obszarach (komunikacja, inteligentny dom i jego wyposażenie, inteligentne ubranie, inteligentny samochód, obniżanie kosztów eksploatacji dzięki energooszczędności) i pozwala 
na choćby częściowe wykorzystanie rozwiązań komercyjnych, znacznie tańszych niż rozwiązania dedykowane wyłącznie opiece medycznej i społecznej. Przykładem jest tu postępująca rewolucja na rynku mobilnego dostępu do Internetu oraz komputerów przenośnych, tabletów i smartfonów, które już $w$ tej stają się nośnikami aplikacji telemedycznych. Rozwiązania telemedyczne są już obecnie eksploatowane w naszym kraju, szczególnie w telekardiologii i telerehabilitacji kardiologicznej [5]. Należy również pamiętać, że ciągle rozwijane są systemy informatyczne w opiece zdrowotnej, w tym szpitalne systemy informacyjne (ang. hospital information system - HIS) oraz systemy informacyjne w lecznictwie otwartym, które, poprzez wymianę danych (w granicach ochrony danych osobowych i tajemnicy służbowej) oraz tworzenie zintegrowanych baz danych powoli zapewnia „przemieszczanie się” wirtualnej kartoteki pacjenta wraz z nim, całodobową dostępność do wszystkich danych dla uprawnionych osób i systemów, oraz podwyższenie efektywności terapii.

\section{MIEJSCE ROBOTÓW REHABILITACYJNYCH WE WSPÓLCZESNYM MODELU USPRAWNIANIA}

Roboty rehabilitacyjne odnalazły swoje miejsce przede wszystkim w formach usprawniania wymagających długotrwałego, wielokrotnego i żmudnego powtarzania przez pacjenta lub wspomagającego go terapeutę) pojedynczych ruchów i/lub ich sekwencji (również $\mathrm{z}$ dynamicznym odciążeniem lub oporem). Wyjątkiem mogą być tu niektóre procedury związane m.in. $\mathrm{z}$ neurorehabilitacją, wymagające indywidualnego podejścia terapeuty do pacjenta, uważnej obserwacji oraz dynamicznej zmiany sposobu terapii - są to procedury zbyt trudne lub zbyt kosztowne do zautomatyzowania, wymagające zaawansowanej sztucznej inteligencji). Do zalet wykorzystania robotów w rehabilitacji należą przede wszystkim:

- potencjalnie większa dostępność oraz krótsze oczekiwanie na rehabilitację,

- możliwość zapewnienia terapii pacjentowi niemal w każdym stanie (przy braku przeciwwskazań do rehabilitacji tego typu),

- wzrost precyzji, powtarzalności oraz (w razie potrzeb) szybkości poszczególnych ruchów i ich sekwencji,

- możliwość zastępowania przez jednego robota nawet grupy terapeutów (np. W reedukacji chodu),

- brak zmęczenia, minimalizacja ryzyka popełnienia błędu wskutek długotrwałego wykonywania jednej czynności,

- pewna (ograniczona) autonomia oraz elastyczność sterowania, coraz większa przyjazność dla pacjenta (również: wygląd), oraz terapeuty (łatwość sterowania, gromadzenia i porównywania danych),

- łatwość utrzymania w czystości, wymagana w placówkach opieki zdrowotnej [2-7].

Najczęstszymi obszarami wykorzystania ww. rozwiązań w warunkach krajowych są:

- usprawnianie kończyn dolnych (roboty: Lokomat, ReoAmbulator, Anymov),

- usprawnianie kończyn górnych (roboty: Armeo, ReoGo),

- przenoszenie i zmiana pozycji pacjenta (prototyp: Noszator).

Rozwiązania prototypowe opracowywane są m.in. w Przemysłowym Instytucie Automatyki i Pomiarów (PIAP), Instytucie Techniki i Aparatury Medycznej (ITAM), ale również na 
uczelniach, m.in. Politechnice Śląskiej, Politechnice Gdańskiej oraz Akademii GórniczoHutniczej, stąd jest realna szansa na pojawienie się tańszych, krajowych rozwiązań.

\section{BILANS SZANS I ZAGROŻEŃ}

Brak ujednolicenia rozwiązań technicznych oraz metodologii badań klinicznych powoduje, że analiza porównawcza poszczególnych rozwiązań jest trudna, szczególnie pod kątem potencjalnych zagrożeń. Opracowanie standardów technicznych oraz procedur oceny i doboru rozwiązań stanowi tu podstawowe wyzwania, podobnie jak wypracowanie jednolitych wskazówek klinicznych oraz wskazań i przeciwwskazań do terapii zrobotyzowanej [8]. W obszarze zrobotyzowanej rehabilitacji domowej oraz telerehabilitacji niezbędna są procedury indywidualnego dopasowania rozwiązania do rzeczywistych potrzeb i możliwości pacjenta (w tym etapu rehabilitacji, jej celów bliższych i dalszych), jego terapeutów i rodziny.

Podstawowe zagrożenia dotyczą również współdziałania układu człowiek-maszyna, czyli pacjent-robot, oraz właściwe reagowanie w sytuacjach awaryjnych. Współdziałanie człowiek-maszyna może być trudniejsze przypadku dzieci, pacjentów w podeszłym wieku oraz $\mathrm{z}$ deficytami neurologicznymi - w tym zakresie warto rozważyć wprowadzenie efektywnego, zrozumiałego wstępnego szkolenia treningu pacjenta i jego opiekunów oraz prostych symulatorów w celu podniesienia efektywności terapii. W przypadku dzieci może to być oczywiście terapia $\mathrm{w}$ formie zabawy - już obecnie zarówno dla dzieci jak i pacjentów dorosłych stosuje się gry motywujące podczas terapii zrobotyzowanej, zarówno wyświetlane na konwencjonalnym telewizorze, jak i dzięki systemom rzeczywistości wirtualnej (ang. virtual reality - VR), również $\mathrm{w}$ ramach biologicznego sprzężenia zwrotnego (ang. biofeedback) ułatwiającego kontrolę poprawności wykonania terapii.

Nie wiadomo obecnie, czy długoterminowe usprawnianie zrobotyzowane niesie ze sobą szkodliwe zmiany wtórne i skutki uboczne, np. w postaci zmodyfikowanych (i dalekich od naturalnych) wzorców ruchu u pacjenta. Wymaga to nie tylko dalszych badań, ale również badań skutków odległych (follow-up).

Dotychczasowe doświadczenia pokazują, że dodatkowe zagrożenia stwarzają przede wszystkim dwie grupy pacjentów:

- badania z zaburzeniami postrzegania i czucia (niewłaściwie dobrane parametry terapii lub niewłaściwie wykonywane ćwiczenia, brak czucia i/lub zgłaszania bólu, możliwość uszkodzenia tkanek, itp.),

- pacjenci „nadambitni”, chcący wykonać ćwiczenie lepiej (lub więcej), a nie po prostu właściwie (przekraczanie zaleceń i zasad bezpieczeństwa, brak zgłaszaniu bólu, możliwość uszkodzenia tkanek, itp.).

Zagrożenia związane $\mathrm{z}$ dehumanizacją opieki zdrowotnej i społecznej w kontekście wykorzystania robotów rehabilitacyjnych nabiera zupełnie nowego znaczenia. Dla części osób wizyta u lekarza lub terapia ambulatoryjna (np. w miejscowej przychodni czy zakładzie rehabilitacji) może być jednym ze sposobów kontaktu z lokalną społecznością (sąsiadami w kolejce), a więc pośrednio: formą interakcji społecznej i terapii. Trzeba pamiętać, że repertuar aktywności kulturalnej i społecznej dostępny polskim emerytom jest ograniczony. W przypadku tej grupy przejście do usprawniania zrobotyzowanego powinno być zrównoważone poprzez np. kluby seniora czy uniwersytety trzeciego wieku.

Nie wiadomo, na ile kontakt $\mathrm{z}$ maszyną zamiast człowieka (lub z człowiekiem niebezpośrednio - poprzez maszynę - jak w przypadku telewizyt) wpływa na zmiany w 
nastroju czy zachowaniu pacjenta [9]. Wymaga to dalszych badań, również w oparciu o doświadczenia zagraniczne. Możemy tu czerpać m.in. z doświadczeń japońskich, gdzie tradycyjna opieka domowa i rodziny wielopokoleniowe przy długowieczności i pracowitości Japończyków muszą być powoli zastępowane przez systemy robotyczne. W niektórych czynnościach codziennego dnia (np. kąpieli) towarzystwo robotów jest nawet bardziej przez nich pożądane od towarzystwa opiekunów-ludzi. Być może również w społeczeństwie polskim trzeba będzie podjąć wysiłek edukacyjny w tym kierunku. Wymaga to jednak połączonego wysiłku specjalistów od nauk medycznych, technicznych oraz humanistów - nie do końca wiadomo bowiem, na ile np. wygląd i forma zwracania się robota do człowieka wpływają na jego postrzeganie przez pacjenta.

\section{KIERUNKI DALSZEGO ROZWOJU}

Postęp techniczny wciąż dostarcza i będzie dostarczał nowych narzędzi i metod terapeutycznych. Kierunki rozwoju robotów medycznych, w tym rehabilitacyjnych, odzwierciedlają potrzeby starzejących się społeczeństwa państw rozwiniętych:

1) z medycznego punktu widzenia:

- roboty pielęgnacyjne i opiekuńcze dla osób w podeszłym wieku,

- roboty terapeutyczne dla dzieci (w tym z autyzmem) oraz osób w podeszłym wieku (np. w przeciwdziałaniu samotności i depresji - w ramach informatyki afektywnej),

- roboty zwiększające niezależność i podwyższające jakość życia pacjenta: egzoszkielety, roboty będące częścią inteligentnego domu,

- systemy telemedyczne ( $\mathrm{w}$ tym zapewniające stały telenadzór nad pacjentami szczególnego ryzyka) i telerehabilitacyjne,

- interfejsy dotykowe (haptyczne),

- możliwość przejścia do innych form sterowania, np. sterowania za pomocą interfejsów mózg-komputer u osób z poważnymi zaburzeniami neurologicznymi,

2) z technicznego punktu widzenia:

- coraz bardziej dokładne systemy mechaniczne,

- zawansowane systemy sztucznej inteligencji, umożliwiające efektywne działanie nawet przy niepełnych i niepewnych danych (np. wnioskowanie na podstawie znajomości zwyczajów pacjenta),

- podwyższenie niezawodności robotów oraz usunięcie lub zniwelowanie znacznej części obecnych czynników ryzyka,

- miniaturyzacja urządzeń w kierunku bioMEMS (ang. bio micro elektro-mechanical systems), bioNEMS (ang. bio nano elektro-mechanical systems) oraz mikrolaboratoriów (ang. lab on a chip).

Roboty przeznaczone do użytku indywidualnego mogą stać się bardziej uniwersalne, łącząc różne $\mathrm{z}$ ww. funkcji (diagnostyczne i wysyłania alertów, podawania leków, podstawowe funkcje telerehabilitacji i opieki). Wynika to nie tylko $\mathrm{z}$ rachunku ekonomicznego, ale również z coraz powszechniejszych tendencji do stosowania medycyny personalizowanej (ang. patient-tailored therapy). Opłacalność utrzymywania wysoce wyspecjalizowanych robotów rehabilitacyjnych może się utrzymać jedynie na oddziałach szpitalnych i w zakładach 
rehabilitacji $-\mathrm{z}$ drugiej strony roboty wyspecjalizowane mogą być lepiej dopasowane do specyfiki danej placówki opieki zdrowotnej.

Coraz szersze wykorzystanie paradygmatu medycyny opartej na faktach (ang. evidence absyd medicine - EBM) powoduje ciągły nacisk na zwiększanie liczby, wiarygodności i powtarzalności badań klinicznych, a szczególnie randomizowanych prób kontrolnych (ang. randomized controlled trials - RCTs). W dłuższym okresie czasu może to spowodować nie tylko stworzenie szeregu wytycznych dotyczących planowania i prowadzenia rehabilitacji oraz stopniową eliminację metod rehabilitacyjnych uważanych za mniej efektywne.

Ma to istotne znaczenie, gdyż coraz częściej polem dyskusji nie tylko specjalistów, ale również opiniotwórczych mediów, staje się nie tylko bezpieczeństwo robotów rehabilitacyjnych, ale również neurotyka (ang. neuroethics), obejmująca wpływ zaawansowanej diagnostyki, nowoczesnych metod leczenia i usprawniania oraz możliwych ingerencji (w tym zarówno neurochirurgicznych, neurochemicznych i innych) w układ nerwowy człowieka. Ten problem może nieść ze sobą jeszcze większe wyzwania, gdyż uważa się, że pierwszy cyborg już istnieje [10].

Szerokie wdrożenie różnych form robotów rehabilitacyjnych może wymusić zmiany organizacyjne w opiece zdrowotnej i społecznej, a co za tym idzie, przyśpieszyć przemiany społeczne w kierunku Społeczeństwa Informacyjnego, ograniczenia kontaktów międzyludzkich i technicyzacji codziennego życia. Analiza ich konsekwencji oraz przeciwdziałanie patologiom może być jednym z ważnych zadań nauk humanistycznych na kolejne lata, a może nawet dziesięciolecia [11-13].

\section{WNIOSKI}

Zmiany technologiczne w kierunku szerszego wykorzystania robotów rehabilitacyjnych mogą nieść ze sobą szereg szans na efektywniejsze usprawnianie oraz szybsze osiąganie samodzielności przez pacjentów. Niemniej jednak znajomość zagrożeń może spowodować wspólne dążenie do stopniowego ich wyeliminowania lub usunięcia skutków ich działań, również w sferze społecznej i etycznej. Ma to szczególne znaczenie w świetle prognoz, że roboty rehabilitacyjne będą miały $\mathrm{w}$ przyszłości dużą siłę marketingowa i ekonomiczną, szczególnie w krajach rozwiniętych, a ich uzupełnieniem i następstwem może być szersza ingerencja w układ nerwowy pacjentów.

\section{References}

[1] Mikołajewska E., Mikołajewski D. Neurorehabilitacja XXI wieku. Techniki teleinformatyczne, (2011) Kraków, Impuls.

[2] Mikołajewska E., Mikołajewski D., Magazyn Pielęgniarki i Położnej 12 (2009) 42.

[3] Mikołajewska E., Mikołajewski D., Rehabilitacja w Praktyce 4 (2010) 49-53.

[4] Mikołajewska E. Mikolajewski D., Pomiary Automatyka Robotyka 5 (2011) 58-64.

[5] Piotrowicz E., Piotrowicz R., European Journal of Preventive Cardiology 20(2 Suppl) (2013) 12-16.

[6] Zsiga K., Edelmayer G., Rumeau P., et al., International Journal of Rehabilitation Research 36(4) (2013) 375-378. 
[7] Dogmus Z., Papantoniou A., Kilinc M., et al., IEEE International Conference on Rehabilitation Robotics 2013 (2013) 1-6.

[8] O'Neill G., Patel H., Artemiadis P., IEEE International Conference on Rehabilitation Robotics 2013 (2013) 1-5.

[9] Jung H. T., Takahashi T., Choe Y. K., et al., IEEE International Conference on Rehabilitation Robotics 2013 (2013) 1-6.

[10] Warvick K. I., cyborg, (2002) London, Century.

[11] Komendziński T., Avant: Journal of Philosophical-Interdisciplinary Vanguard 2(3) (2012) 334-343.

[12] Komendziński T., Toruński Przegląd Filozoficzny 2 (1999) 131-142.

[13] Mikołajewska M., Mikołajewski D., International Letters of Social and Humanistic Sciences 8 (2013) 86-90. 